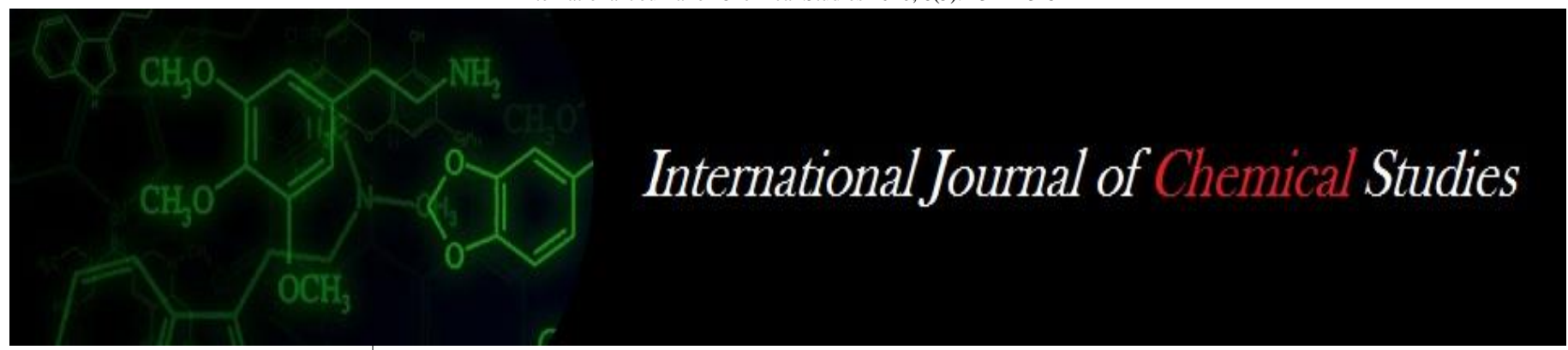

P-ISSN: 2349-8528

E-ISSN: 2321-4902

www.chemijournal.com

IJCS 2020; 8(5): 2321-2325

(C) 2020 IJCS

Received: 28-06-2020

Accepted: 07-08-2020

\section{Soufil S Malek}

College of Forestry, Navsari

Agricultural University, Navsari,

Gujarat, India

\section{MJ Dobriyal}

Rani Lakshmi Bai Central

Agricultural University, Jhansi,

Madhya Pradesh, India

\section{RP Gunaga}

College of Forestry, Navsari

Agricultural University, Navsari,

Gujarat, India

BS Desai

College of Forestry, Navsari

Agricultural University, Navsari,

Gujarat, India

BK Bhatt

ASPEE College of Horticulture,

Navsari Agricultural University,

Navsari, Gujarat, India

Corresponding Author:

Soufil S Malek

College of Forestry, Navsari

Agricultural University, Navsari,

Gujarat, India

\section{Performance of Coleus aromaticus Benth. Under Sapota-Jatropha based horti-medicinal agroforestry system}

\author{
Soufil S Malek, MJ Dobriyal, RP Gunaga, BS Desai and BK Bhatt
}

DOI: https://doi.org/10.22271/chemi.2020.v8.i5af.10650

\section{Abstract}

Performance of Coleus aromaticus Benth. under sapota-jatropha based horti-medicinal agroforestry system were evaluated during the study. Plant height was recorded highest with treatment T2 $(34.95 \mathrm{~cm})$ at 90 DAP (Days after planting). Number of branches (19.28), leaves (422.36), root $(22.99 \mathrm{~cm})$, number of roots $(63.90)$ and basal diameter $(12.12 \mathrm{~mm})$ were observed maximum at $90 \mathrm{DAP}$ under treatment T1. Maximum leaf thickness observed with treatment T4 $(0.98 \mathrm{~mm})$ while leaf length $(9.60 \mathrm{~cm})$, leaf width $(6.72 \mathrm{~cm})$ and leaf area $\left(32.60 \mathrm{~cm}^{2}\right)$ found maximum with treatment T1. Fresh weight of leaves $(443.75$ $\mathrm{g})$, branches (105.48 g), shoot (575.75 g), root (17.34 g) and total biomass (579.63 g/plant) also observed significantly higher with treatment $\mathrm{T} 1$. The maximum dry weight of leaves, branches, shoot, root and total biomass, maximum fresh yield, dry yield, oil recovery, oil yield and BCR was recorded maximum with treatment $\mathrm{T} 1$ (C. aromaticus Benth. under sapota + jatropha system).

Keywords: Coleus aromaticus, Horti-medicinal agroforestry, BCR, Oil recovery

\section{Introduction}

National Agroforestry Policy, 2014 and sub-mission on agroforestry under National Mission on Sustainable Agriculture (NMSA), envisages the promotion of tree planting on farmlands and development of various agroforestry models with diverse cropping system for economic and ecological security. Mainly due to the economic benefits farmers have adopted the trend of growing trees around agricultural land. Sapota or Sapodilla (Manilkara zapota (L.) P.Royen) belongs to family Sapotaceae is one of the potential and widely adopted tropical fruit crop grown in southern Gujarat under rainfed as well as in irrigated condition. Ratanjyot or Fig nut or Physic nut (Jatropha curcus L.) is a perennial, monoecious shrub or small tree up to $6 \mathrm{~m}$ high belongs to family Euphorbiaceae. It is easy to establish, grows relatively quickly producing good seeds for 20 years. It is one of the main crops being promoted for biodiesel production in several countries globally (Pandey et al., 2006) ${ }^{[18]}$. Jatropha oil is famous as a biofuel also can be used as a substitute of diesel and kerosene, as a lubricant and in manufacturing of soaps and candles. Being reach in nitrogen, the seed cake is an excellent source of organic manure (Punia et al., 2006) ${ }^{[21] .}$

Monoculture of fruit trees or jatropha being risk-prone and broad spacing provided to this crops is an opportunity for an intercrop under the plantation and to generate additional income with improving productivity per unit area as a result of efficient land utilization and improved agroecological conditions. Even though forest cover of Gujarat state is poor but it is fairly rich in terms of biodiversity, 201 medicinal plant species (74\%) are indigenous of Gujarat from which 148 species $(74 \%)$ are naturally grown and 53 species $(26 \%)$ are cultivated (Singh and Parabia, 2003) ${ }^{[23]}$. The rising of the global market for naturopathy products leads and encourage the farmers to turn towards the cultivation of medicinal and aromatic plants. The limitation of land for major agricultural crops poses a challenge to promote sole cultivation of medicinal plants on prime agricultural land in spite of their commercial potential. Therefore intercropping of medicinal plants with fruit and other shrubs/ trees as a subsidiary crop in terms of utilization of space and an additional income source for small and marginal farmers is a most suitable and viable option. Besides the cereals, vegetables and flowers, the medicinal plants are also grown as intercrops with varieties of tree plantations such as forestry 
Plantations, block plantations and orchards of horticultural tree species under agroforestry or horti-medicinal system.

Coleus aromaticus Benth (syn. Plectranthus amboinicus) known as ajma pan in Gujarati is a member of Lamiaceae. It is a green, perennial shrub, having heart-shaped and leathery leaves with scalloped edges, leaves are strongly aromatic and having a strong pungent flavour. Fresh leaves of $C$. aromaticus contain $0.04-0.05 \%$ volatile oil, with majorly carvacrol (Rout et al., 2012) ${ }^{[22]}$. Traditionally it is also used to cure severe bronchitis, asthma, diarrhoea, epilepsy, vaginal discharge, renal and vesical calculi and fever. It is reported to act as an antilithotic, chemopreventive, antiepileptic and antioxidant, aromatic, carminative, diaphoretic, tonic, stimulant (El-hawary et al. 2013 [7], Kirtikar et al, 2003 [11], Chopra et al. $1986^{[4]}$ ). Jain (2012) ${ }^{[8]}$ reported that tribal people use the juice of leaves in sore throat, wound healing and swelling disorder. The fleshy leaves also consumed as delicious fritters by locals. Malek et al. (2018) ${ }^{[16]}$ reported that $C$. aromaticus is an easily propagated species through stem cuttings of any part even without hormone treats under nursery condition.

Thakur et al. (2017) ${ }^{[27]}$ advocated agroforestry as a viable option for commercial cultivation of Medicinal and aromatic plants in India. Incorporating medicinal and aromatic plants under horti-medicinal agroforestry system will promote sustainable agricultural land use, increased productivity and income to the farmers of south Gujarat. Present investigation will not only widen the range of options to the farmers for crop diversification, but also provides ample scope for production of raw material to agro and medicinal plant based industries which in turn will reduce the pressure on natural forest.

\section{Material and Methodology}

The study involved the propagation and cultivation of $C$. aromaticus Benth. under sapota - jatropha based hortimedicinal agroforestry system. Field experiment was conducted under support irrigation conditions during September - March (2016-17) at Navsari Agricultural University, Navsari, Gujarat to study cultivation and intercropping of Coleus aromaticus Benth. under SapotaJatropa based agroforestry system. The twelve year old plantation of sapota (Manilkara acharas (Mill) Fosberg.) at
$10.0 \times 10.0 \mathrm{~m}$ spacing grown with five year old plantation of jatropha (Jatropha curcus L.) at $2.5 \times 5 \mathrm{~m}$ spacing were used for intercropping study.

C. aromaticus Benth. was intercropped at 50 X $50 \mathrm{~cm}$ spacing under different treatments i.e. $\mathrm{T}_{1}$-under sapota-jatropha, $\mathrm{T}_{2}$ under sapota, $\mathrm{T}_{3}$-under jatropha, $\mathrm{T}_{4}$-sole crop with $\mathrm{RBD}$ design and 5 replication. The gross plot size was $10 \times 5 \mathrm{~m}$ (50 $\mathrm{m}^{2}$ ). Soil was brought to a fine tilth by giving about two deep ploughing (cultivator, disc plough, rotary plough). Weeds stubbles, roots etc. were removed. Beds of $10 \mathrm{~m}$ length and 5 $\mathrm{m}$ width were prepared. Nitrogen, phosphorus and potash were applied at the rate of 40:60:50 kg/ha (RDF) for the intercropped specie as per agronomic schedule (Kirtikar, 2003) ${ }^{[11]}$. Weeding was done as per requirement after sowing. Irrigations were applied at an interval of 15 days regularly after transplanting. No Serious pest and disease were observed during experimentation period. The observations on growth and yield such as plant height $(\mathrm{cm})$, total number of branches/plant, total number of leaves/plant, basal diameter, root length $(\mathrm{cm})$, total number of roots/plant, fresh weight of plant (leaves, branches and roots) (g/plant), dry weight of plant (leaves, branches and roots) (g/plant), yield of plant/plot, total yield (q/ha). Extraction of oil from $C$. aromaticus Benth. leaves were done by using steam/hydro distillation unit (Rout, 2012) ${ }^{[22]}$.

Economic feasibility of the intercropping of $C$. aromaticus Benth. (ajma pan) in sapota - jatropha based agroforestry system was calculated from each combination or system by considering all input, cost and net return from all components.

\section{Result and discussion}

The biometrical data of intercrop C. aromaticus Benth. under different combination of sapota - jatropha plantation were recorded. Number of branches (19.28), number of leaves (422.36), length of root $(22.99 \mathrm{~cm})$, number of roots $(63.90)$, basal diameter $(12.12 \mathrm{~mm})$, leaf length $(9.60 \mathrm{~cm})$, leaf width $(6.72 \mathrm{~cm})$ and leaf area $\left(32.60 \mathrm{~cm}^{2}\right)$ were recorded maximum under treatment $\mathrm{T} 1$ (C. aromaticus Benth. under sapota + jatropha) at 90 DAP (Days after planting). While, maximum plant height $(34.95 \mathrm{~cm})$ was significantly higher under the T2 (C. aromaticus Benth. under sole sapota) and maximum leaf thickness, $0.98 \mathrm{~mm}$ was recorded in treatment T4 (sole crop) (Table 1).

Table 1: Biometrical observations of $C$. aromaticus Benth. plants at 90 DAP under sapota-jatropha based horti-medicinal agroforestry system

\begin{tabular}{|c|c|c|c|c|c|c|c|c|c|c|}
\hline Treatmt & \begin{tabular}{|c|} 
Plant height \\
$(\mathbf{c m})$
\end{tabular} & $\begin{array}{c}\text { Total number of } \\
\text { Branches } \\
\text { /plant }\end{array}$ & $\begin{array}{c}\text { Total number of } \\
\text { Leaves/plant }\end{array}$ & $\begin{array}{l}\text { Root } \\
\text { length } \\
\text { (cm) }\end{array}$ & $\begin{array}{c}\text { Number of } \\
\text { roots/ } \\
\text { plant }\end{array}$ & $\begin{array}{l}\text { Basal dia- } \\
\text { meter } \\
(\mathbf{m m})\end{array}$ & $\begin{array}{c}\text { Leaf } \\
\text { thickness } \\
(\mathrm{mm})\end{array}$ & $\begin{array}{c}\text { Length of } \\
\text { leaves } \\
(\mathrm{cm})\end{array}$ & $\begin{array}{l}\text { Width of } \\
\text { leaves } \\
\text { (cm) }\end{array}$ & $\begin{array}{l}\text { Leaf } \\
\text { area } \\
\left(\mathbf{c m}^{2}\right)\end{array}$ \\
\hline $\mathrm{T} 1$ & 32.38 & 19.28 & 422.36 & 22.99 & 63.90 & 12.12 & 0.83 & 9.60 & 6.72 & 32.60 \\
\hline $\mathrm{T} 2$ & 35.94 & 10.56 & 256.72 & 18.85 & 41.51 & 9.81 & 0.91 & 8.08 & 5.68 & 25.60 \\
\hline T3 & 20.37 & 11.40 & 192.00 & 16.14 & 25.20 & 7.92 & 0.79 & 8.22 & 4.92 & 19.00 \\
\hline $\mathrm{T} 4$ & 16.04 & 10.60 & 135.80 & 19.32 & 29.57 & 9.28 & 0.98 & 7.36 & 5.04 & 15.00 \\
\hline S.Em. \pm & 0.56 & 0.75 & 11.54 & 1.08 & 1.19 & 0.41 & 0.03 & 0.24 & 0.04 & 1.00 \\
\hline $\begin{array}{c}\text { C.D. } \\
\text { at } 5 \%\end{array}$ & 1.74 & 2.31 & 35.55 & 3.33 & 3.68 & 1.25 & 0.10 & 0.74 & 0.11 & 3.07 \\
\hline C.V. \% & 4.31 & 11.56 & 9.17 & 11.19 & 5.96 & 8.30 & 7.45 & 5.79 & 1.30 & 8.65 \\
\hline
\end{tabular}

Treatment details: T1 (C. aromaticus Benth. under sapota - jatropha), T2 (C. aromaticus Benth. under sapota), T3 (C. aromaticus Benth. under jatropha),T4(SoleC.aromaticusBenth.)

Jharna Chetri (2016) ${ }^{[9]}$ also reported performance of C. aromaticus Benth., with significantly maximum height, number of leaves, collar diameter, number of secondary roots, shoot length, root length, fresh weight of shoot and root, dry weight of shoot and, yield per plot and yield per hectare under Arjun (Terminalia arjuna) as compared kalam, haldu and open condition. Kumar et al. (2010) ${ }^{[13]}$ grown safed musli as intercrop in pre-bearing tamarind plantation of six years age and recorded significantly higher plant height $(11.13 \mathrm{~cm})$ and numbers of functional leaves (26.73) compared to crop grown in open area $(8.93 \mathrm{~cm}$ and 21.60 respectively) at 90 days after planting (DAP). Significantly higher dry weight of tuber was 
recorded under tamarind based intercropping situation (9.25 g/plant) compared to sole cropping in open area (5.86 g/plant). Similar findings were reported by Maheswarppa and Nanjappa (2001) ${ }^{[14]}$ in galangal (Koempferia galangal L.) intercropped with coconut and Karikalan et al. (2002) ${ }^{[10]}$ in gymnema (Gymnema sylvertre Retz.) intercropped with kapak (Ceiba pentandra). Pandey et al. (2017) ${ }^{[20]}$ also concluded that at time of harvesting of Zingiber officinale L., maximum fresh rhizome yield and total number of fingers per plant, plant height, length of rhizome, width of rhizome and survival percent of ginger was higher under sapota + jatropha or jatropha based agro-forestry systems as compared to sole cropping.

Table 2: Fresh and dry biomass of different plant parts of C. aromaticus at 90 DAP sapota-jatropha based horti-medicinal agroforestry system

\begin{tabular}{|c|c|c|c|c|c|c|c|c|c|c|}
\hline \multicolumn{6}{|c|}{$\begin{array}{r}\text { Fresh weight } \\
\end{array}$} & \multicolumn{5}{|c|}{ Dry weight } \\
\hline Treatment & $\begin{array}{c}\text { Leaves } \\
\text { (g/plant) }\end{array}$ & $\begin{array}{c}\text { Branches } \\
\text { (g/plant) }\end{array}$ & $\begin{array}{c}\text { Shoot } \\
\text { (g/plant) }\end{array}$ & \begin{tabular}{|c|} 
Root \\
(g/plant)
\end{tabular} & Total biomass (g/plant) & \begin{tabular}{|c|} 
Leaves \\
(g/plant)
\end{tabular} & $\begin{array}{c}\text { Branches } \\
\text { (g/plant) }\end{array}$ & $\begin{array}{c}\text { Shoot } \\
\text { (g/plant) }\end{array}$ & \begin{tabular}{|c|} 
Root \\
(g/plant)
\end{tabular} & $\begin{array}{c}\text { Total biomass } \\
\text { (g/plant) }\end{array}$ \\
\hline T1 & 443.75 & 105.48 & 575.75 & 17.34 & 579.63 & 53.25 & 16.26 & 58.85 & 3.84 & 62.69 \\
\hline $\mathrm{T} 2$ & 250.63 & 51.27 & 365.48 & 10.27 & 305.74 & 25.06 & 9.41 & 20.94 & 1.84 & 22.79 \\
\hline T3 & 146.54 & 19.60 & 186.87 & 5.16 & 240.24 & 16.12 & 8.37 & 19.50 & 0.79 & 20.29 \\
\hline $\mathrm{T} 4$ & 183.62 & 26.16 & 218.58 & 7.00 & 225.93 & 18.36 & 5.86 & 10.89 & 2.31 & 13.20 \\
\hline S.Em. \pm & 6.27 & 2.75 & 8.74 & 0.69 & 9.62 & 0.74 & 0.59 & 2.01 & 0.07 & 1.99 \\
\hline C.D. at $5 \%$ & 19.32 & 8.47 & 26.93 & 2.14 & 29.64 & 2.27 & 1.83 & 6.21 & 0.22 & 6.13 \\
\hline C.V. \% & 4.90 & 10.86 & 5.19 & 13.96 & 5.69 & 5.24 & 11.91 & 14.62 & 6.47 & 13.38 \\
\hline
\end{tabular}

Treatment details: T1 (C. aromaticus Benth. under sapota - jatropha), T2 (C. aromaticus Benth. under sapota), T3 (C. aromaticus Benth. under jatropha), T4 (Sole C. aromaticus Benth.)

Fresh weight of leaves (443.75 g/plant), branches (105.48 $\mathrm{g} / \mathrm{plant})$, shoot (575.75 g/plant), root (17.34 g/plant) and total biomass (579.63 g/plant) observed significantly higher with the treatment T1. Similarly maximum dry weight of leaves was observed with treatment T1 (53.25 g/plant) and minimum with T3 (16.12g/plant), whereas weight of branches (16.26 $\mathrm{g} /$ plant), shoot $(58.85 \mathrm{~g} / \mathrm{plant})$, root $(3.38 \mathrm{~g} / \mathrm{plant})$ and total biomass (62.69 g/plant) was observed significantly higher with the treatment $\mathrm{T} 1$ and minimum with the treatment $\mathrm{T} 4$ (Table 2).
Maximum fresh yield (59.91 kg/plot and 11.97 ton/ha), dry yield $(37.19 \mathrm{~kg} / \mathrm{plot}$ and $1.44 \mathrm{ton} / \mathrm{ha})$, oil recovery $(0.05 \%)$ and oil yield $(1.69 \mathrm{~kg} / \mathrm{plot}$ and $1.316 \mathrm{ton} / \mathrm{ha})$ were recorded significantly highest with the treatment T1 (Table 3). Divya et al. (2006) [5] reported that in Jatropha curcus based agroforestry systems maximum reduction in growth and yield of intercrops at closer spacing $(2 \mathrm{~m} \times 2 \mathrm{~m})$ of jatropha compare to wider spacing $(4 \mathrm{~m} \times 3 \mathrm{~m})$. Similarly intercropping of summer groundnut var. Dh 86 and ICGV 93468 with Jatropha curcas recorded significant higher yield by 1.85 and 1.84 t/ha respectively, (Munish Kumar et al. 2007) ${ }^{[17]}$.

Table 3: Total yield, Oil recovery (\%) and Oil yield of $C$. aromaticus Benth. leaves on fresh and dry weight basis at 90 DAP under sapotajatropha based horti-medicinal agroforestry system

\begin{tabular}{|c|c|c|c|c|c|c|c|}
\hline \multirow{2}{*}{ Treatmen } & \multicolumn{2}{|c|}{$\begin{array}{l}\text { Yield (Fresh weight) } \\
\end{array}$} & \multicolumn{2}{|c|}{\begin{tabular}{|c|} 
Yield (Dry weight) \\
\end{tabular}} & \multirow{2}{*}{$\begin{array}{c}\text { Oil recovery } \\
(\%)\end{array}$} & \multirow{2}{*}{\multicolumn{2}{|c|}{\begin{tabular}{c|c} 
Oil yield & Oil yield \\
(Kg/Plot) & $($ Ton/ha) \\
\end{tabular}}} \\
\hline & Leaves yield (kg/plot) & Leaves yield (Ton/Ha) & Leaves yield (kg/plot) & Leaves yield (Ton/Ha) & & & \\
\hline $\mathrm{T} 1$ & 59.91 & 11.97 & 7.19 & 1.44 & 0.05 & 3.00 & 0.60 \\
\hline $\mathrm{T} 2$ & 46.87 & 9.36 & 5.62 & 1.12 & 0.04 & 1.87 & 0.37 \\
\hline T3 & 25.64 & 5.12 & 3.08 & 0.62 & 0.04 & 1.03 & 0.21 \\
\hline $\mathrm{T} 4$ & 22.95 & 4.59 & 2.75 & 0.55 & 0.03 & 0.69 & 0.14 \\
\hline S.Em. \pm & 0.53 & 0.72 & 0.21 & 0.04 & - & 0.11 & 0.07 \\
\hline C.D. at $5 \%$ & 1.63 & 2.21 & 0.63 & 0.13 & - & 0.33 & 0.21 \\
\hline C.V.\% & 2.73 & 18.51 & 8.84 & 8.79 & - & 12.95 & 40.59 \\
\hline
\end{tabular}

Treatment details: T1 (C. aromaticus Benth. under sapota - jatropha), T2 (C. aromaticus Benth. under sapota), T3 (C. aromaticus Benth. under jatropha), T4 (Sole C. aromaticus Benth.)

Different morphometric parameters such as plant height $(57.78 \mathrm{~cm})$, numbers of leaves $(516.56)$, length of root $(39.29$ $\mathrm{cm})$, number of roots $(54.27)$, basal diameter $(15.36 \mathrm{~mm})$, fresh weight of leaves $(660.58 \mathrm{~g})$, fresh weight of shoot $(848.06 \mathrm{~g})$, fresh weight of root $(33.35 \mathrm{~g})$ and total fresh biomass $(857.27 \mathrm{~g} /$ plant), dry weight of leaves (52.62 g), dry weight of branches (39.38 g), dry weight of shoot $(92.40$ $\mathrm{g} /$ plant), dry weight of root $(8.72 \mathrm{~g})$ and total dry biomass $(101.12 \mathrm{~g} / \mathrm{plant})$, maximum fresh yield of roots $(2.20 \mathrm{~kg} / \mathrm{plot}$ and $1.33 \mathrm{ton} / \mathrm{ha})$ and dry yield of roots $(0.58 \mathrm{~kg} / \mathrm{plot}$ and 0.48 ton/ha) of $C$. forskohlii were recorded maximum under Sapota + Jatropha based agroforestry system, (Malek et al., 2020) ${ }^{[15]}$. Krishnamurthy et al. (2006) ${ }^{[12]}$ reported growing Centella asiatica in high rainfall localities under open and partial shade of mango orchards giving more yield under mango orchards.
These all authors support the high yield of intercrops under jatropha system which also reflected in our results. Solanki et al. (2014) ${ }^{[26]}$ reported performance of tuber was medicinal crops under sapota-jatropha based three tier agroforestry system with higher yield in sole crop as compared to intercrop with kalihari (1.79 q/ha), kali musli (1.38 q/ha) and safed musli $(1.81 \mathrm{q} / \mathrm{ha})$ but had higher economic returns was more from agroforestry system as compared to sole crop. Acorus calamus was intercropped with Morus alba, an increase in biomass yield of Acorus calamus intercropped (32.25 gm) compared to the control (28.96 gm) (Chamoli et al. 2013) ${ }^{[3]}$. Oil content of ginger (Zingiber officinale), turmeric (Curcuma longa) and asparagus (Asparagus officinalis), maximum amount $(3.94 \%, 4.37 \%$ and $6.45 \%)$ was recorded under litchi based agroforestry system while minimum $(3.24 \%, 3.92 \%$ and $5.52 \%$ ) was recorded in sole cropping of medicinal plants. On 
the other hand, total organic matter percent was highest $(8.70 \%$ and $11.10 \%)$ in mango based agroforestry system (Ali et al. 2013) ${ }^{[1]}$

The highest Benefit Cost Ratio (BCR) was recorded with treatment T1 (3.97- C. aromaticus Benth. under sapota + jatropha system) resulting net return of Rs 255031, per hactre followed by T2 (3.23- $C$. aromaticus Benth. under sole sapota); T3 (1.59- C. aromaticus under jatropha); and minimum with T4 (1.31- C. aromaticus Benth. as sole crop)
(Table 4). Solanki et al. (2014) ${ }^{[25]}$ recorded higher BCR for intercrops compared to sole crop when cultivated under sapota-jatropha based three-tier agroforestry system as with basil (1.67), kalmegh (1.46) and mint (1.40). Pandey et al. (2016) ${ }^{[19]}$ also reported higher $\mathrm{B}$ : C ratio 4.85(sapota with turmeric) and 2.76 (sapota- jatropa + ginger) than sole turmeric and ginger crops. Awasthi et al. (2005) ${ }^{[2]}$ also found in mango

Table 4: Economics of $C$. aromaticus Benth. Cultivation under sapota-jatropha based horti-medicinal agroforestry system.

\begin{tabular}{|c|c|c|c|c|c|c|c|}
\hline \multirow[b]{2}{*}{ Treatments } & \multicolumn{3}{|c|}{ Income (Rs/ha) } & \multirow[b]{2}{*}{$\begin{array}{c}\text { Total cost } \\
\text { Of production (Rs/ha) }\end{array}$} & \multirow[b]{2}{*}{$\begin{array}{c}\text { Total gross income } \\
\text { (Rs/ha) }\end{array}$} & \multirow[b]{2}{*}{$\begin{array}{c}\text { Net income } \\
\text { (Rs/ha) }\end{array}$} & \multirow[b]{2}{*}{ BCR } \\
\hline & \begin{tabular}{|c|} 
Sapota \\
(Fruit) (Rs/ha)
\end{tabular} & $\begin{array}{c}\text { Jatropha } \\
\text { (Seed) (Rs/ha) }\end{array}$ & $\begin{array}{c}\text { Dried leaves / Dried plant } \\
\text { (Rs/ha) }\end{array}$ & & & & \\
\hline T 1 & 42255 & 10980 & 287550 & 85754 & 340785 & 255031 & 3.97 \\
\hline $\mathrm{T} 2$ & 52125 & 0 & 224965 & 85754 & 277090 & 191336 & 3.23 \\
\hline $\mathrm{T} 3$ & 0 & 13380 & 123094 & 85754 & 136473 & 50720 & 1.59 \\
\hline $\mathrm{T} 4$ & 0 & 0 & 110172 & 84400 & 110172 & 25772 & 1.31 \\
\hline
\end{tabular}

Treatment details: T1 (C. aromaticus Benth. under sapota - jatropha), T2 (C. aromaticus Benth. under sapota), T3 (C. aromaticus Benth. under jatropha), T4 (Sole C. aromaticus Benth.)

Sapota + jatropha system) resulting net return of Rs 255031, per hactre followed by T2 (3.23- C. aromaticus Benth. under sole sapota); T3 (1.59- C. aromaticus under jatropha); and minimum with T4 (1.31- C. aromaticus Benth. as sole crop) (Table 4). Solanki et al. (2014) ${ }^{[25]}$ recorded higher BCR for intercrops compared to sole crop when cultivated under sapota-jatropha based three-tier agroforestry system as with basil (1.67), kalmegh (1.46) and mint (1.40). Pandey et al. (2016) ${ }^{[19]}$ also reported higher B: C ratio 4.85(sapota with turmeric) and 2.76 (sapota- jatropa + ginger) than sole turmeric and ginger crops. Awasthi et al. (2005) ${ }^{[2]}$ also found in mango (monocropping) and mixed crop integrating ginger, bay leaf and pepper on an average gross and net returns were more by 3.41 and 2.45 times in mixed cropping respectively. The results of present study revealed high BCR for C. aromaticus Benth. under sapota + jatropha system with high monetary returns as compared to other crops can be better option for adoption. Dutt and Thakur (2004) ${ }^{[6]}$ suggest O. sanctum and Tagetes minuta with poplar at different spacing gives more return than monocropping. Solaiappan et al. (2002) ${ }^{[24]}$ also reported sapota, sesbania and greengram or blackgram based hort-silvi agricultural system a suitable and highly remunerative for rainfed vertisol region.

\section{Conclusion}

The economic feasibility of intercropping of this medicinal crop C. aromaticus Benth. with sapota- jatropa was calculated higher under sapota + jatropha based horti-medicinal agroforestry system. Further, intercropping under sole sapota and sole jatropa plantation also found more rewarding financially than sole coleus cultivation. These findings will help in promoting the propagation and intercropping of these medicinal crops under hortisilvi system like sapota- jatropa in south Gujarat.

\section{References}

1. Ali MF, Hanif MA, Bari MS, Akher SA, Fatema U. Phytochemical Assessment of Some Medicinal Plants under Different Agroforestry Systems. Bangladesh Research Publications Journal. 2013; 8(4):186-190.
2. Awasthi OP, Singh J, Saroj PL. Yield and economics of mango based multi species cropping system in Bastar plateau of Chattisgarh. Indian Journal of Agroforestry. 2005; 7(2):10-14.

3. Chamoli M, Varshney VK, Srivastava PK, Rajiv Pandey, Rameshwar Dayal. Assessment of Biomass Yield, Essential Oil and $\beta$-asarone content of Acorus calamus L. Intercropped with Morus alba L. Journal of Essential Oil Bearing Plants. 2013; 16(6):763-770. DOI: 10.1080/0972060X.2013.862081.

4. Chopra RN, Nayar SL, Chopra IC. Glossary of Indian Medicinal Plants, Council of Scientific and Industrial Research, New Delhi, 1986, 57.

5. Divya MP, Santhi R, Ramesh KR. Evaluation of suitable intercrops for Jatropha curcus based agroforestry system. Indian Journal of Agroforestry. 2006; 8(2):1-4.

6. Dutt V, Thakur PS. Bio-economics of cropping systems combining medicinal and aromatic herbs with commercial timber tree species. Indian Journal of Agroforestry. 2004; 6(1):1-7.

7. El-hawary SS, El-sofany RH, Monem AR, Ashour RS, Sleem AA. Seasonal variation in the composition of Plectranthus amboinicus (Lour.) Spreng essential oil and its biological activities. American Journal of Essential Oils and Natural Products. 2013; 1(2):11-18.

8. Jain AK, Dixit A, Mehta SC. Wound healing activity of aqueous extracts of leaves and roots of Coleus aromaticus in rats. Acta poloniae pharmaceutica and drug research 2012; 69(6):1119-1123.

9. Jharna Chetri. Performance of Coleus aromaticus (Ajma pan), Centella asiatica (Brahmi) and Psoralea corylifolia (Babchi) grown under different tree species in South Gujarat. M.Sc. (Agroforestry). A thesis submitted to the N.A.U, Navsari, 2016.

10. Karikalan TV, Divya MP, Gopi D. Effect of intercropping and nitrogen management on growth and yield of medicinal plants under kapok. Indian Journal of Agronomy. 2002; 4(2):88-93. 
11. Kirtikar KR, Basu BD. Indian Medicinal Plants, 2nd edn., Lalit Mohan Basu, Allahabad, 2003, 1970.

12. Krishnamurthy R, Chandorkar MS, Kalzunkar EG, Pathak JM, Gupta R. Studied on agronomic practices for growing Centella asiatica (L.) urban in high rainfall localities under open and partial shade of mango orchards. Indian Journal of Horticulture. 2006; 63(1):7680.

13. Kumar RD, Sreenivasulu GB, Prashanth SJ, Jayaprakashnarayan RP, Nataraj SK, Hegde NK. Performance of safed musli (Chlorophytum borivilianum. L) in tamarind plantation as intercrop and as sole crop in open area. International Journal of Agricultural Sciences. 2010; 6(1):359-360.

14. Maheshrappa HP, Nanhjappa HV. Effect of planting material, plant population and organic manure on growth components and yield of galangal (Kaempferia galangal) when grown as intercrop in coconut garden. Indian Journal of Agricultural Sciences. 2001; 71(3):183-186.

15. Malek SS, Dobriyal MJR, Thakur NS, Desai BS, Gunaga RP. Coleus forskohlii (Poir.) Briq. A Suitable Intercrop of Horti-Medicinal Agroforestry System for South Gujarat. Trends in Biosciences. 2020; 13(3):162-167.

16. Malek SS, Dobriyal MJR, Gunaga RP, Desai BS. Effect of cutting types and IBA treatment on propagation of aromatic herb ajama paan (Coleus aromaticus Benth.), MFP news. 2018; 30(3):11-15.

17. Munish Kumar, Singh RA, Ekhlaq Haider, Chaudhary HP. Range Agroforestry system of Jatropha curcas and Arachis hypogaea. Range Management and Agroforestry. 2007; 28(2B):346-347.

18. Pandey AK, Preetesh kumara, Mandal AK. Cultivation of Jatropha curcus (Ratanjot) in Madhya Pradesh, India. Indian Journal of Agroforestry. 2006; 8(2):28-31.

19. Pandey SBS, Jadeja DB, Manohar NS, Tandel MB. Studied the economic comparison of intercropping of ginger and turmeric under Sapota Jatropha based agroforestry system in south Gujarat. International Journal of Science, Environment and Technology. 2016; 5(5):3635-3642.

20. Pandey SBS, Mukta Pandey, Jadeja DB, Tandel MB, Nayak D. Growth and yield of ginger (Zingiber officinale L) under Sapota-Jatropha based agroforestry systems in south Gujarat. Journal of Pharmacognosy and Phytochemistry. 2017; 6(6):247-251.

21. Punia MS, Kureel RS, Pandey A. Status and potential of tree borne oilseed (TBOS) in biofuel production of India. Indian Journal of Agroforestry. 2006; 8(2):80-86.

22. Rout OP, Acharya R, Mishra SK, Rashmibala Sahoo. Pathorchur (Coleus aromaticus): a review of the medicinal evidence for its phytochemistry and pharmacology properties. International Journal of Applied Biology and Pharmaceutical Technology. 2012; 3(4):348-355.

23. Singh AP, Parabia M. Status of medicinal plants consumption by the pharmaceutical industries in Gujarat state. Indian Forester. 2003; 123(2):198-212.
24. Solaiappan U, Senthivel S, Chellaiah N, Paulpandi VK. Horti-silvi-agricultural system for rainfed vertisols of Tamil Nadu. Madras Agricultural Journal. 2002; 89(13):75-78.

25. Solanki VK, Jadeja DB, Parmar MR. Performance of tuber medicinal crops under sapota-jatropha based threetier agroforestry system. International Journal of Agricultural Sciences. 2014; 10(1):412-415.

26. Solanki VK, Jadeja DB, Tandel MB. Performance of herbal medicinal crops under sapota-jatropha based threetier agroforestry system. International Journal of Agricultural Sciences. 2014; 10(1):267-271.

27. Thakur NS. Horti-medicinal agroforestry systems: A potential land use for commercial cultivation of medicinal and aromatic plants, 2017. https://www.researchgate.net/publication/320125875_Ho rtimedicinal_agroforestry_systems_A_potential_land_use _for_commercial_cultivation_of_medicinal_and_aromati c_plants 